\title{
C-reactive protein concentration as a guide to antibiotic therapy in acute leukaemia
}

\author{
KP SCHOFIELD, F VOULGARI, DI GOZZARD, ${ }^{*}$ MJ LEYLAND, ${ }^{*}$ NJ BEECHING, $\dagger$ \\ J STUART
}

From the Department of Haematology, Medical School, University of Birmingham, and *Department of Haematology and $\dagger$ Department of Communicable and Tropical Diseases, East Birmingham Hospital

SUMMARY Serial monitoring of the serum C-reactive protein (CRP) concentration was performed, using a one-hour laser-immunonephelometric assay, during 29 episodes of infection in 22 neutropenic patients with acute leukaemia. Serum CRP increased to above a diagnostic level of $100 \mathrm{mg} / \mathrm{l}$ in all 29 episodes and continued to rise progressively until appropriate antibiotics, or granulocytes, were given when it fell with a half-life of approximately three days. Serial study of the serum concentration was of value in detecting occult or unresolved bacterial infection and provided an objective means of monitoring the response to antibiotic and granulocyte therapy.

Infection, when unrecognised or treated ineffectively, is the commonest cause of death in neutropenic patients with acute leukaemia. Because of the lack of granulocytes, clinical and radiological signs of infection are often inadequate and the diagnosis of potentially-fatal infection may be delayed. Empirical treatment with a broad-spectrum antibiotic combination, given intravenously, may be life saving but there are few objective guidelines to indicate when bacterial infection is responding and for how long intravenous antiobiotics should be continued. An objective method for quantifying the inflammatory response might therefore be of clinical value in guiding antibiotic policy and indicating when granulocytes should be given. ${ }^{1}$

Acute infection, and other causes of an inflammatory response, will induce hepatic synthesis $^{2}$ of C-reactive protein (CRP) and other acutephase reactant proteins so that a rise in serum concentration occurs within a few hours or days. ${ }^{3}$ $\mathrm{C}$-reactive protein has been widely studied as an acute-phase reactant $t^{4}$ and the rise in serum concentration may be detected within one hour of experimentally-induced endotoxaemia. ${ }^{5}$ Rapid measurement of CRP is now possible using laser immunonephelometric $^{6}$ or rate immunonephelometric $^{7}$ assays and the present study was designed to investigate the value of the one-hour laser immunonephelometric assay as a guide to the effectiveness of antibiotic therapy in acute leukaemia.

Accepted for publication 5 January 1982

\section{Patients and methods}

Twenty-two neutropenic adults with acute leukaemia at diagnosis or in relapse, who were admitted with infection or developed infection during admission, were treated by a broad-spectrum antibiotic combination given intravenously. Venous blood for CRP assay, using a one-hour laser nephelometric method, ${ }^{6}$ was taken daily, or on several days per week, and either processed immediately, stored at $0-4^{\circ}$ for one to two days, or the serum separated and stored at $-20^{\circ} \mathrm{C}$. Results were telephoned to ward staff so that antibiotic therapy could be modified where indicated.

An additional 72 patients, without leukaemia, who required acute admission to an Infectious Diseases Unit because of bacterial (31), viral (27) or $P$ vivax malarial (14) infection, were also studied during the first few days of admission to determine the relative magnitude of the CRP response to different types of infection. All 72 patients had laboratory confirmation of the type of infection and their peak serum CRP concentration on days 1-3 of admission was compared with the mean normal value for 60 healthy adults.

\section{Results}

Twenty-nine episodes of probable bacterial infection in the 22 neutropenic patients were studied. Infection was confirmed bacteriologically in 14 episodes and radiologically in four; six others had definite clinical evidence of infection and five had a 
pyrexial illness highly suggestive of infection and in which no other cause of pyrexia was found. The serum CRP concentration rose to $>100 \mathrm{mg} / \mathrm{l}$ in all 29 episodes (normal level: $0-7 \mathrm{mg} / \mathrm{l}$ ).

When there was a delay in starting antibiotics, despite a CRP level of $>100 \mathrm{mg} / \mathrm{l}$, the serum concentration continued to rise in seven episodes and "plateaued" in one. In nine patients who died with uncontrolled leukaemia and unresolved infection despite antibiotics, the CRP concentration again rose progressively until death. A clinical response to antibiotics occurred in 17 episodes (in four, this required a change of antibiotics) and the CRP concentration fell progressively with a half-life of approximately three days. In six of these episodes, antibiotics were stopped when the CRP level was still $>100 \mathrm{mg} / \mathrm{l}$, but it continued to fall to below $100 \mathrm{mg} / \mathrm{l}$ in one to two days; in 11 episodes, antibiotics were not stopped until the CRP concentration was $<100 \mathrm{mg} / \mathrm{l}$ and it continued to fall thereafter as the episode resolved. Seven episodes of infection responded inadequately to the initial antibiotic combination. In four, the CRP concentration did not fall until either the antibiotic combination was
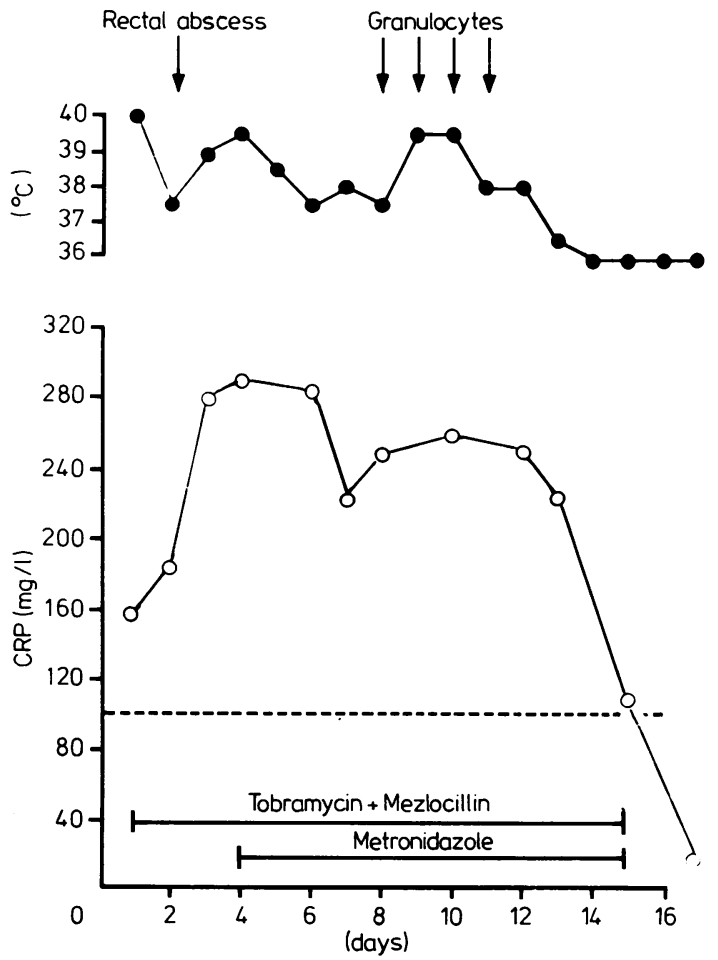

Fig. 1 Effect of daily granulocyte transfusions on temperature and serum CRP concentration after incomplete response of a rectal abscess to antibiotics. changed or daily granulocytes added (Fig. 1). In one patient (Fig. 2) there was apparent clinical resolution of an $E$ coli throat infection with return of temperature to normal and antibiotics were stopped despite a CRP concentration of $170 \mathrm{mg} / \mathrm{l}$. A further rise in CRP then preceded the recurrence of pyrexia and isolation of $E$ coli from blood cultures so that antibiotics were restarted using a different combination; this caused a fall in CRP with full clinical resolution. An incomplete response to antibiotics also occurred in one patient with right lower lobe consolidation; the CRP concentration fell to $82 \mathrm{mg} / \mathrm{l}$, plateaued for seven days, then rose to $135 \mathrm{mg} / \mathrm{l}$ with cavity formation on the chest $x$-ray. In the final patient, antibiotics were stopped at a CRP concentration of $84 \mathrm{mg} / \mathrm{l}$ at a time when there was clinical resolution of pneumonia, but the falling level plateaued and rose again four days later to $140 \mathrm{mg} / \mathrm{l}$ when antibiotics were restarted as pyrexia returned.

In the 72 non-leukaemic patients with acute infection, the peak serum CRP concentration during the first three days of admission was studied to determine whether the diagnostic level of $100 \mathrm{mg} / \mathrm{l}$ for bacterial infection also applied to other types of infection. A peak serum concentration of $>100 \mathrm{mg} / \mathrm{l}$ was reached in only seven of the 27 patients with viral infection. The mean peak CRP concentration on days 1-3 of viral infection was nine times higher than the upper limit of the normal range $(7 \mathrm{mg} / \mathrm{l})$ for 60 healthy adults, whereas the peak concentrations for bacterial and protozoal infection were 21 times and 16 times higher respectively. Thus a quantita-
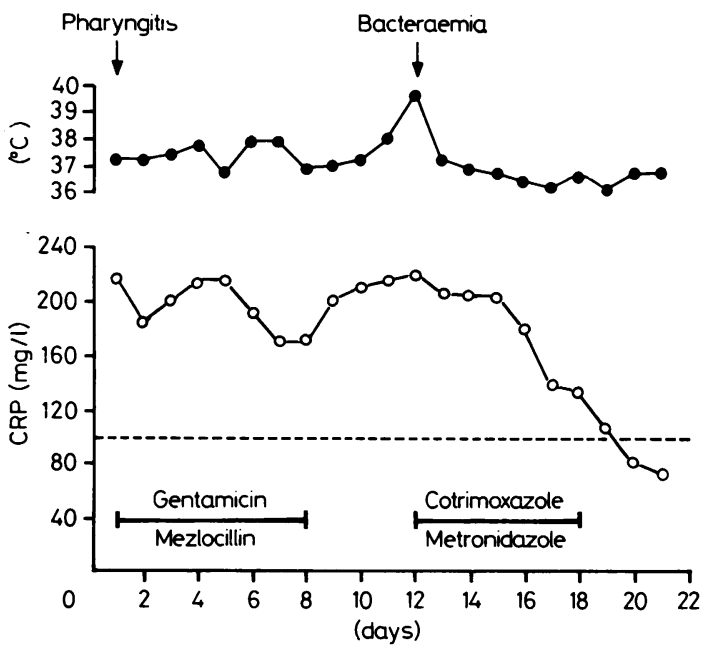

Fig. 2 Value of serial CRP monitoring during incomplete response of $E$ coli throat infection to antibiotics and subsequent bacteraemia. 
tively smaller CRP response occurs in viral compared with other types of infection.

\section{Discussion}

This study has confirmed, in 29 episodes of probable or confirmed bacterial infection in 22 neutropenic patients with acute leukaemia, that the serum CRP concentration rises to above the previouslyestablished diagnostic level of $100 \mathrm{mg} / \mathrm{l}^{68}$ It is important to determine whether viral infection will induce a similar rise but our study of 27 acute viral infections, in patients without leukaemia, suggests that it may not since a lower peak CRP level is achieved. We have not studied patients with fungal infection.

Although a rise in serum CRP concentration may therefore be of diagnostic value in bacterial infection, the decision to start antibiotics in the neutropenic patient with pyrexia is often made on empirical clinical grounds. Despite the unreliability of pyrexia for the diagnosis of infection, this empirical approach should continue to be applied, particularly out of laboratory hours when the one-hour CRP assay is not normally available. Daily blood samples, which may be stored at $0-4^{\circ} \mathrm{C}$ over a weekend, should be taken for subsequent assay, however, so that antibiotics can be stopped if there is no rise in CRP. If the concentration does reach $100 \mathrm{mg} / \mathrm{l}$, blood specimens should continue to be taken since the CRP level is of particular value as a guide to subsequent antibiotic management.

Whenever antibiotics were not started, despite a CRP concentration of $>100 \mathrm{mg} / \mathrm{l}$, or if the patient failed to respond to antibiotics, the CRP continued to rise. In the nine patients who died with unresolved infection, the concentration rose progressively until death. It is clear that failure of the CRP concentration to fall indicates that the infection has not responded. If an appropriate antibiotic is used, or control of the infection is achieved with granulocyte transfusions, then the CRP falls progressively, with a half-life of approximately three days, to $<100 \mathrm{mg} / \mathrm{l}$. If this rate of fall is maintained below $100 \mathrm{mg} / \mathrm{l}$, it is usually safe to stop intravenous antibiotics but, if the patient remains neutropenic, the CRP concentration should continue to be monitored on at least alternate days to detect new, or recurrent, infection. In our experience, an apparent clinical response to antibiotics is not a reliable guide to stopping antibiotics if the CRP level is still $>100 \mathrm{mg} / \mathrm{l}$.

We have previously shown that the CRP concentration does not rise to $>100 \mathrm{mg} / \mathrm{l}$ in response to active leukaemia, blood transfusion or bloodcomponent therapy, or cytotoxic therapy, even in the presence of a pyrexial reaction. ${ }^{68}$ Thus meas- urement of CRP is clearly a more specific test for bacterial infection than a rise in temperature. The sensitivity of the two tests seems comparable: in the present, plus a previous, ${ }^{6}$ study giving a total of 63 episodes of infection, CRP rose above $100 \mathrm{mg} / \mathrm{l}$ and the temperature rose above $37^{\circ} \mathrm{C}$ on the same day in 49 episodes, pyrexia occurred first in seven episodes, and CRP rose first in seven. As an infection resolves, a raised temperature will fall but this is an inadequate guide since pyrexia is often low grade, or absent, or remitting, and the precision and scale $\left(37-40^{\circ} \mathrm{C}\right)$ of temperature recording are too insensitive.

Serial study of the serum CRP concentration, as a measure of the inflammatory response, can therefore be used as a screening test for occult bacterial infection and to assess subsequently whether inflammation is subsiding during antibiotic therapy. CRP is synthesised in the liver ${ }^{2}$ but the nature of the stimulus to the liver from a site of infection is unknown. While the CRP assay, as a screening test, shows good balance between sensitivity and specificity, ${ }^{9}$ it cannot be used to detect infection within 10 days of other acute tissue damage, such as surgery, since a high serum concentration, in proportion to the extent of tissue damage, will inevitably be present. With this limitation, the recent development of the laser nephelometric CRP assay ${ }^{\circ}$ provides a rapid and objective means of monitoring the response of bacterial infection to antibiotic and granulocyte therapy in clinical trials and for individual patient care.

We are indebted to the Leukaemia Research Fund for financial support; Dr BJ Boughton and Professor AM Geddes for allowing us to study patients under their care; Dr MJ Bolton and Dr AJ Howitt for providing blood specimens; and Mrs M Meakin for technical assistance. Presented to the British Society for Haematology (London) 1982.

\section{References}

'Higby DJ. Granulocyte transfusions: where now? N Engl J Med 1981;305:636-68.

${ }^{2}$ Hurlimann J, Thorbecke GJ, Hochwald GM. The liver as the site of C-reactive protein formation.J Exp Med 1966;123:365-78.

${ }^{3}$ Koj A. Acute-phase reactants. In: Allison AC, ed. Structure and function of plasma proteins Vol 1. London: Plenum Press. 1974:73-131.

${ }^{4}$ Pepys MB. C-reactive protein fifty years on. Lancet $1981 ; \mathbf{i}: 653-7$.

5 Yen-Watson B, Kushner I. Rabbit CRP response to endotoxin administration: does-response relationship and kinetics. Proc Soc Exp Biol Med 1974;146:1132-6.

${ }^{6}$ Rose PE, Johnson SA, Meakin M, Mackie PH, Stuart J. Serial study of C-reactive protein during infection in leukaemia. $J$ Clin Pathol 1981;34:263-6.

' Gill CW, Bush WS, Burleigh WM, Fischer CL. An evaluation of a $\mathrm{C}$-reactive protein assay using a rate immunonephelometric procedure. Am J Clin Pathol 1981;75:50-5. 
Mackie PH, Crockson RA, Stuart J. C-reactive protein for rapid diagnosis of infection in leukaemia. $J$ Clin Pathol 1979;32:1253-6.

${ }^{9}$ Kenny MW, Worthington DJ, Stuart J, Davies AJ, Farr M, Davey PG, Chughtai MA. Efficiency of haematological screening tests for detecting disease. Clin Lab Haematol 1981;3:299_ 305 .

Requests for reprints to: Professor J Stuart, Department of Haematology, Medical School, University of Birmingham, Birmingham B15 2TJ, England. 